\title{
THEOLOGICAL EDUCATION AS DEVELOPMENT IN VANUATU: \\ 'WAYFARING' AND THE TALUA MINISTRY TRAINING CENTRE
}

\author{
Steve Taylor ${ }^{1} \&$ Phil King ${ }^{2}$
}

\begin{abstract}
Education is essential to development. In Pacific cultures, in which the church is a significant presence, theological education can empower agency and offer analytical frames for social critique. Equally, theological education can reinforce hierarchies and dominant social narratives. This paper provides an account of Presbyterian theological education in Vanuatu. Applying an educative capability approach to a theological education taxonomy proposed by Charles Forman brings into focus the interplay between economics, context, and sustainability as mutual challenges for both development and theological education. However Forman's model does not accurately reflect the realities of Vanuatu. An alternative frame is proposed, that of wayfaring, in which knowledge-exchange is framed as circulating movements. Wayfaring allows theological education to be imagined as a development actor that affirms local agency, values networks, and subverts centralising models. This alternative model provides a way to envisage theological education, both historically in Vanuatu and into an increasingly networked future, as an actor in Pacific development.
\end{abstract}

Keywords: Vanuatu; theological education; wayfaring; Christianity; development WHY THEOLOGICAL EDUCATION IN DEVELOPMENT?

Education is essential to development, defined by the UNDP as an expanding of the richness of human life (HDRO Outreach 2018). Literacy opens doors, provides access to new ways of seeing the world, and makes possible ways of thinking that are critical and contextual.

In the Pacific, it is impossible to consider the essential role of education in development without considering Christianity - and, by extension, theological 
education. While it is tempting for development to drink deeply from the wells of secularisation, and ignore the role of Christianity, in the Pacific, the role of religion, including theological education, must be considered. ${ }^{3}$ Christianity is a book-based approach to faith. Hence much of the early education in the Pacific was done through theological colleges, teaching literacy in order that the Bible might be understood and hymn books read. New identities between distinct cultures and language groups began to be formed in the relationships that were cultivated between students inside and outside theological classrooms. Following the Second World War, Pacific nations began moving toward independence. For Helen Gardner (2013), the skills and abilities nurtured in indigenous leaders by theological education - public speaking (preaching), administration (setting church meeting agendas), and budget setting (church annual accounts) - were a significant force in nation building (see also Clarke, this issue). For Tracey Banivanua Mar (2016), decolonisation in the Pacific was nurtured through transnational, including educational, networks. The work of Gardner and Mar invites us to re-examine the role of theological colleges and Pacific church forums as transnational networks that produced knowledge exchange essential for development.

While theological education can enhance development, it can equally be a hindrance. Education, like development and theology, is never neutral. Education can serve to alienate students from their local context. New ways of thinking might be possible, but what is the role of the hidden curriculum, especially when education is theological? A recent Masters thesis from a well-known theological college in the Pacific explored a local contextual theology. When it came to a chapter on the authority of Scripture, the footnotes referenced only Western theologians. How can theological education empower a Pacific theology equipped to respond to Pacific challenges? Jenny Te Paa-Daniel (2018) has called church leaders in the Pacific to engage more deeply in public debate and the reality of human suffering. She points to an entangling of church and state and embedded patterns of patriarchy among church leaders. Does theological education enhance or hinder the richness of human life, including in gender relationships?

These challenges require an examination of theological education in light of the richness of human life sought in development. For Gorringe (2004, 19-20), Christianity cannot think theologically 'without taking account of the Church's collusion with imperialism, patriarchy and racism'. As development enters into dialogue with theology, so theology must dialogue with development. One way to examine these general reflections is though empirical study. This essay considers the role of theological education in development through a study of Talua 
Ministry Training Centre (Talua). Situated by the sea on Espiritu Santo, the largest island in Vanuatu, Talua trains ordained ministers and church leaders for the entire Presbyterian Church of Vanuatu (Presbitirin Jyos Blong Vanuatu, $\mathrm{PCV})$. The PCV is the largest denomination in Vanuatu. ${ }^{4}$ The PCV became selfgoverning in 1948, an early example of church independence in the Pacific. The Presbyterian Church of Aotearoa New Zealand is a partner church of the PCV. This paper examines archival documents and books held in New Zealand by the Presbyterian Research Centre. ${ }^{5}$ In addition, participant observation through a mutual exchange served to deepen the analysis. ${ }^{6}$

Talua is approached methodologically as a microhistory, in the belief that larger patterns and wider narratives (in this case of theological education as development) can be discovered in 'small worlds' (Brooks, DeCorse, and Walton 2008; Ginzburg 2012, 213). Focusing on the specific story of Talua enables us to pay close attention to human agency and to consider theological education in the practice of everyday lives, including at the intersections of local and global (Lockwood 2004). For Magnusson (2006), the close-up focus possible in a micro-history enables a theoretical sensitivity toward agency and justice, particularly in relation to minorities in matters of ethnicity, race, and gender. Using a UNDP definition of development enables us to understand the potential for theological education to be a development actor: considering the potential to expand and enrich human life.

In reading the archival documents, we focus on educational capability rather than theological belief. Paying attention to educational capability requires examining location, curriculum, practices of learning, and the economic, educational, and demographic makeup of the student cohort. It is an application of the work of Indian economist and Nobel Peace Prize recipient Amartya Sen (1985) who has argued for a 'capability approach', which understands development as a tool enabling people to reach the highest level of their ability, through granting freedom of action. Sen's approach provides a way to examine the relationship between theological education and development, particularly questions in relation to local agency and context.

To reflect on theological education and development in general, our analysis of Talua proceeds in three steps: first, to present an account of the history of Presbyterian theological education in Vanuatu, second, to test (and find wanting) a taxonomy for theological education in the Pacific proposed by Charles Forman, and third, to apply a concept of wayfaring in order to theorise a distinctly Pacific understanding of theological education as development. We argue that wayfaring is congruent with Pacific understandings of being a con- 
tinent, criss-crossed by ocean currents as concrete for travel as any mainland motorway. ${ }^{7}$ Wayfaring is also specific to the history of theological education in Vanuatu and an image central to how Talua currently imagines itself. Wayfaring provides a way to understand development and theological education as able to respond with agility to the diversity of ever shifting contexts, in the past as groups with distinct languages combined to become a nation (Vanuatu has 113 different languages) and into the future as globalisation disrupts nation states. In short, wayfaring provides a way to focus on the 'and' in the interplay between theological education and development.

\section{DEVELOPMENT AND THEOLOGICAL EDUCATION IN VANUATU}

Development has an inbuilt tension. The word assumes the need for change. An existing local situation requires improvement. Historically, external agencies have sought to be actors in bringing development. They understand themselves as seeing possibilities, having technology, and being willing to act. At the same time, conventional wisdom says that change is more likely to be sustained if it is generated from within. Hence the tension: how might external agencies participate with the local in meaningful development? A kilometre down the road from Talua is an abandoned concrete building. A sign declares this was a store, built with local Ni-Vanuatu labour, opened in 2000, thanks to financial gifts from the US Peace Corps and the World Council of Churches. The interplay in development between local (labour) and external (funds) has resulted not in economic development but in an abandoned building. At the same time, all over Vanuatu, Ni-Vanuatu people build, not by importing expensive concrete, but by constructing shelter from local bush materials.

The interplay between local and external is a recurring theme in theological education. When Fiama Rakau tells the story of theological education in Vanuatu, he begins with a story of how, in 1849 , two Ni-Vanuatu men swam out to a visiting ship, seeking transport to Samoa in order to receive theological training. Rakau $(1988,1)$ tells this story to assert that theological education in Vanuatu 'is not foreign, neither was it imposed.' The assertion can be read as an affirmation of local agency. In a newly independent country (the Republic of Vanuatu was established in 1980, just eight years prior to Rakau's narration), the foreign can easily be dismissed as external and imposed. If theological education is a gift from afar, then it is an external influence, to be treated with suspicion. In drawing on this story, Rakau is positioning indigenous people as historic agents in seeking theological education. They are local actors in their development as leaders for their communities. 
A repeated theme in the archival material on the history of theological education in Vanuatu is the priority of local agency. The first theological college, Ministry Training Centre was located in Aname, Aneityum. Students worked in gardens, ensuring a 'practical gospel work during training.' This enabled education to be free. Teaching people that they might be able to read the Bible and learn the will of God ... for themselves' points to theological education as enhancing literacy and empowering local agency. ${ }^{10}$ Rakau $(1988,2)$ considered this empowerment as essential in development: 'Presbyterian Mission was forced to give up its dependence upon the [London Missionary Society] teachers. Theological education was thus a historic actor in development in Vanuatu. It provided opportunities through literacy and took seriously the interpretive agency of Ni-Vanuatu people in regard to belief.

Kamisetea was the first Ni-Vanuatu pastor, ordained in 1895 , the year that Tangoa Training Institution was established. The documented aims of the Tangoa suggest a commitment to equality, local agency, and contextualisation. In regard to equality, there is reference to the essential parity of the intellectual powers, irrespective of race or colour' (Rakau 1988, 6). Local people and local cultures were valued both culturally and linguistically. 'The missionaries ... had to make sure that the language used should be acceptable for communicating the Christian Gospel' (Makikon 1988). This affirmation needs to be read in relation to Vanuatu as one of the most linguistically fragmented nations in the world. When education occurs in a shared language, which in Vanuatu included Bislama, English, and French, it provided ways to form identity across groups with distinct languages and cultures. This coherence was essential in Vanuatu: a country with 113 languages (Mitchell 2004). Hence theological education becomes essential for development in Vanuatu, including playing a role in the development of a new trade language (Bislama), an essential factor in forming national identity.

Tangoa was established with the belief that each one of these languages and cultures was valued in theological education. The College called for teaching that 'assimilated the thought-forms of the native culture' and educated 'students to the nature of the responsibility for an indigenous church' (Rakau 1988, 6, 7). In regard to local agency, the goal was a 'self-governing Vanuatu Church .... [Through the] inclusion of island teachers [as theological educators] .... The gradual assumption by the Vanuatu Church of the cost of training' (Rakau $1988,7)$. Though these aims for local empowerment, including in governance, leadership, language, culture, education and economics, were articulated in 1895 they continue to sound surprisingly contemporary. Theological education was understood as playing a role in the development of Vanuatu, nurturing an 
independent church.

A third Presbyterian institution, Aulua Training College was established in 1977. As with Tangoa, local agency was central.'Aulua expresses the determination to move towards self-help' (Rakau 1988, 11). Similarly, the values of local culture and life were affirmed, evident in the call for training to take 'place within the culture and life of the people. Aulua was formed three years before independence for Vanuatu. Gardner (2013) has argued that Presbyterianism - which in structure has a national assembly, regional presbyteries and local congregations - made a unique contribution toward an independent Vanuatu. First, the interplay of national, regional, and local bodies in the PCV assisted in interweaving disparate cultures and communities together. The relationships that develop inside and outside a theological classroom contribute to this interweaving. For Gardner $(2013,128)$, Presbyterianism provided a way of organising that 'transcended village and island boundaries ... a political form that translated readily to the standards of contemporary democracy'. Second, an organisation that included governance groupings of grassroots voices allowed the [church] openly to back the call for independence, as decisions were made from the body of the church rather than imposed by a church hierarchy' (Gardner 2013, 128). Third, given that each body (assembly, presbytery, and congregation) has a governance group, Presbyterianism as a structure helped in the development of administrative and political skills. Gardner $(2013,142)$ argues this with specific reference to theological education, noting the role of Presbyterian trained ministers in Ni-Vanuatu politics during and after Vanuatu's independence in 1980. ${ }^{11}$ This is consistent with Rakau $(1988,11)$, who describes a leadership crisis in the PCV after independence, as numerous clergy became active in national politics.

A fourth college, Talua Ministry Training Centre, was established in 1988. Geographically, Aulua was situated on a small and isolated island. In time, local people claimed back the land on which the college had been established. In contrast, the site for Talua, which was originally a place where sick people were brought to die, was hoped to be 'a place of life' (Pacific Vanuatu Talua Ministry Training Centre, 6). Talua is a portmanteau of two of the earlier colleges: Tangoa and Aulua. Talua was committed to being bilingual, ecumenical, and self-supporting (Vanuatu Talua Project 1985). Consistent with the values, first of the Ministry Training Centre, then Tangoa Training Institution, and Aulua Training College, contextual questions remained at the forefront of teaching at Talua.

The curriculum paid attention to contextual theologies. Church history began with Vanuatu and Pacific history, before Reformation and Presbyterian. Theology began with God in Vanuatu, in other 
churches and in the Bible. Being human explores different views of being human, including Vanuatu, science, anthropology and secular. (Vanuatu Talua Project 1985)

This description locates theological education firmly in Vanuatu, including in church history and theology. In seeking to understand the richness of being human, Talua sought to engage a range of new ways of thinking, critical and contextual.

However, this priority on the local needs to be read in light of the increasing diversity of contexts within the Pacific. "Will life and work at Talua prepare students for the leadership needed in Vanuatu today, or will it uproot them from their own soil?' (Rakau 1988, 17-8). In the face of independence and the resulting shortage of capable leadership, three distinct contexts are evident in the archival literature: local villages, emerging national challenges, and overseas educational experiences. These diverse contexts, as groups with distinct languages became one nation at the same time as globalisation disrupts nation states, present challenges for both theological education and development. We see a sense of local and emerging national responsibility in the challenge given to Talua to produce graduates 'fit for service, not only back in the villages, but fitting equally into the political, economic, religious and social changes of Vanuatu today' (Rakau 1988, 17).

For Mar $(2016,221)$, open access to education in the Pacific was 'a dose of smelling salts', undoing the work of colonisation through the provision of resources, networks, and critical pedagogies. Mar $(2016,172)$ described how access to higher education in the Pacific in the 1960s was essential in producing independence leaders who 'quickly became part of a wider transnational network of radical thinking. This account affirms the overseas education experience and this echoes in the experience of Talua. One report from Pastor Oli, having attended a Bible College Principals' Conference, observed that the 'standard in Vanuatu is very low in comparison' to other theological colleges in the Pacific (Vanuatu Talua Project 1985). Talua is formed, three years later, aware of the need to raise standards of theological education in Vanuatu. ${ }^{12}$ Yet overseas education experiences frequently resulted in students who were perceived to be 'alienated from their own people' (Rakau 1988, 12). This suggests that the very benefits of overseas education could result in a 'shadow' side: graduates no longer able to serve in local village communities. Theological education and development share a similar struggle. How does the external, whether overseas education or finances for a concrete building, participate with the local in enabling meaningful change? 
In sum, examination of the archival material relating to the history of Presbyterian theological education in Vanuatu reveals the priority of local agency. The forming of Ministry Training Centre, Tangoa, Aulua, and Talua share a commonality: a clear commitment to local empowerment. Theological education has played a role in development in Vanuatu, expanding the richness of human life as Ni-Vanuatu cultures are affirmed and church structures provided which enhance the journey toward independence and train leaders for Vanuatu's national challenges. At the same time a set of tensions has become evident. How to equip leaders for Pacific contexts as diverse as a local village and an expanding capital city? How to improve education standards, without creating leaders 'alienated from their own people' (Rakau 1988, 12)? Exposed to overseas educational experiences, theological education in Vanuatu needed to change. How might these changes occur, the external participate with the local in enriching human life? We continue to analyse the microhistory of Talua, through a conversation with the taxonomy of theological education in the Pacific proposed by Charles Forman.

\section{THEOLOGICAL EDUCATION AND FORMAN'S PACIFIC TAXONOMY}

In the late 196os, Charles Forman (1969) argued that theological education in the Pacific had gone through two distinct stages: one 'historic' and the other more 'recent'. The historic model of 'Pacific style' theological education involved denominations establishing a general school to teach practical and theological topics (Forman 1969, 155). By paying close attention to local language and patterns, a contextualised and economically self-sustaining mode of training was possible.

In the 1960s, dramatic changes occurred that changed the patterns of theological education. Forman's 'recent' model involved the appearance of new theological institutions that he considered to be 'theological schools in the true sense' (Forman 1969, 156). These new institutions were centralised and ecumenical, offering university level theological education in English. The following table (Table 1) clarifies Forman's taxonomy. An educational capability map is proposed, involving seven factors: location, curriculum, practices of learning, economic resources required, wider education context, demographics, and teaching resources.

This table helps us appreciate the complexity of development when it comes to theological education. The historic model is more localised in contextual practise. It requires fewer financial resources. It does not create dependency by relying on 'foreign personnel' (Forman 1969, 162). The use of the 'heart language' in education lowers entry barriers and encourages local theology and culture. 
Table 1. Forman's taxonomy of historic and recent theological institutions.

\begin{tabular}{|c|c|c|}
\hline & Historic & Recent \\
\hline Location & $\begin{array}{l}\text { Close to villages. } \\
\text { Students connected to familial } \\
\text { networks. }\end{array}$ & $\begin{array}{l}\text { In major urban centres. } \\
\text { Students removed from familial } \\
\text { networks. } \\
\text { Requires travel and increased } \\
\text { accommodation costs. }\end{array}$ \\
\hline Curriculum & $\begin{array}{l}\text { Taught in vernacular. } \\
\text { Curriculum includes theology, } \\
\text { literacy, and gardening, to } \\
\text { ensure sustainability. }\end{array}$ & $\begin{array}{l}\text { Courses taught in English. } \\
\text { Greater library resources, } \\
\text { but in an 'alien' tongue. } \\
\text { Implementation of international } \\
\text { higher education benchmarking. } \\
\text { Curriculum includes theology } \\
\text { and sociology. } \\
\text { Theoretical frames allow } \\
\text { critique of context and tradition. }\end{array}$ \\
\hline $\begin{array}{l}\text { Practices of } \\
\text { learning }\end{array}$ & $\begin{array}{l}\text { Lower pre-requisites. } \\
\text { Less time for study, due } \\
\text { to practical gardening } \\
\text { requirements. }\end{array}$ & $\begin{array}{l}\text { Higher pre-requisites. } \\
\text { More time for study, due to a } \\
\text { decrease in the time needed for } \\
\text { gardening. }\end{array}$ \\
\hline Economic & $\begin{array}{l}\text { Cheaper, requiring less staff } \\
\text { and based on a gardening } \\
\text { economy, which is essentially } \\
\text { self-sufficient. }\end{array}$ & $\begin{array}{l}\text { Requires significant external } \\
\text { funding, both for staff and } \\
\text { student support. }\end{array}$ \\
\hline Educational & $\begin{array}{l}\text { Theological colleges were } \\
\text { the main educational option } \\
\text { and gained the most capable } \\
\text { students. }\end{array}$ & $\begin{array}{l}\text { The rise in educational } \\
\text { options across the Pacific } \\
\text { means theological colleges are } \\
\text { competing for students. }\end{array}$ \\
\hline Demographics & Average age 40. & Younger cohort in twenties. \\
\hline $\begin{array}{l}\text { Teaching } \\
\text { resources }\end{array}$ & One teacher. & $\begin{array}{l}\text { Team of specialists, often with a } \\
\text { high degree of dependence on } \\
\text { foreign personnel. }\end{array}$ \\
\hline
\end{tabular}

In the recent model, the search for enhanced (Western) standards results in theological students being 'alienated' from their local context. Centralisation is likely to provide intellectual reflection freed from local tradition and opens up the possibility of a more critical educational process. At the same time, the pedagogical frames and resources being used are foreign. Using English enables access to a wider range of text books, yet few English theological books 
in the 1960s would have dealt directly with the contextual issues facing Pacific peoples. Costs are likely to be higher, due to the greater number of specialised staff. Students spend less structured time tending gardens. This increases time for study and reflection. It also increases the costs of study, given that food needs to be purchased rather than grown.

Forman's taxonomy helps us pay attention to development factors inherent in theological education, including economic sustainability, pedagogy, and contextuality. Centralised ('recent') models of theological education provide efficiencies of scale yet also increase costs. They remove students from local contexts yet provide space for critical reflection. Recent models are expensive and influenced by Western pedagogical resources.

An anecdote is illustrative. In reading the archives, the following critique was made of an educational programme run by the PCV. A PCV newsletter (1989, 1) noted that 'After an academic training only ... the pupils cannot cope with the village situation, they cannot handle a bush knife, gardening is difficult and strange. In this anecdote, the shift away from the use of practical skills and toward a more academic programme reduced the graduating students' ability to remain connected with their village. This disconnection is practical, since the bush knife is a crucial technology of work and self-sufficiency. This disconnection is also cultural, given that the garden is at the heart of Melanesian culture' according to Pastor Selerik, Principal of Talua (pers. com., 2017). How to respond to an education that diminishes the richness of Melanesian gardening life? Such are the complexities of development.

FORMAN'S TAXONOMY AND THE REALITIES OF VANUATU

We have outlined Forman's taxonomy in general, using an educative 'capability' approach in order to bring to the fore an interplay between economics, context, and sustainability. Centralising can increase opportunity yet decrease the ability to operate in 'heart languages'; it can achieve economies of scale yet results in increased costs of living. Being at a distance from a village context provides space for critical reflection yet can diminish connections back among village communities. How do these complexities at the heart of Forman's taxonomy play out in the specific case of Talua?

When Forman's taxonomy is applied to Talua, we find that Talua is in fact a blend of the 'historic' and 'recent' in the provision of theological education. Forman's binary does not apply to Talua College. 
Regarding location, Talua has an educational capability that is both 'historic' and 'recent'. It is 'recent', given it is close to Luganville, Vanuatu's second largest centre. It is equally 'historic', in that Talua is at significant distance geographically from other islands. This makes it difficult for students to return home, resulting in long periods of separation during the course of study. From its beginning, Presbyterian theological education has Forman's description of a more centralised model.

Regarding curriculum, Talua is operating in the 'recent' model but within limits. Education is in English. The diploma curriculum is accredited by the South Pacific Association of Theological Schools (spats) and is thus set within a Pacific context. The Bachelor of Ministry (BMin) is accredited by the Asia Theological Association (ATA), shaped by different - 'foreign' - cultural influences. Many students at Talua are not proficient in English and require assistance. Classes led by Ni-Vanuatu lecturers revert to Bislama when discussing deep concepts as it is easier for them to express themselves.

Regarding study requirements, Talua is still largely in the 'historic' model. Some students enter with fairly low standards of education. A report to the Presbyterian Assembly in the late 1980 os noted the value of candidates who have graduated from secondary school because they have the necessary literacy skills (Talua Committee 1988). The BMin assumes a higher set of pre-requisites and is taught by staff who have PhDs. Hence with regard to teaching resources, Talua is closer to the recent model. At the same time, a 1988 calendar showed a weekly pattern that began with daily worship for thirty minutes at 7:30 am, and concluded at 4:30 pm (Talua Committee 1988). Topics for pastoral students included theology (four hours), homiletics (two hours), agriculture (three hours), Old Testament (two hours), New Testament (three hours), Gospel and culture (two hours), Pastoral Studies (three hours), and Church history (two hours). There was allocated time for study, sport, work, and choir. A similar pattern was at work when one of us visited Talua for ten days in 2017. It was striking how much time was spent in scheduled classroom activities, in contrast to contemporary higher education which expects high levels of independent research and reading.

Regarding economic resources, students at Talua live in a 'mission village' and spend time daily tending to their gardens. An internal report (Pacific Vanuatu Talua Ministry Training Centre, 6) described a situation in which 'staff and students are given enough plots of land to do gardening. There are more than enough food crops in the gardens. This reduces costs, but also reduces the time 
available for study. Fees at Talua are cheap in relation to other institutions in Vanuatu, and even more so for the cost of studying outside the country.

This speaks to the costs of the 'recent' model. Despite being closer in some respects to the 'historic' model, Talua continues to rely on external funding. Talua has lived with a large amount of debt for many years. However, financial dependence on external sources like benefactors and partner churches should not be seen as a negative thing per se. Many academic institutions across the globe rely on external sources of funding and endowments; and there is little angst or concern among elite theological institutions over whether their finances derive from 'local' or 'foreign' sources. Talua's economic struggles point to the difficulty of operating a theological institution in any contemporary context, including within the Pacific economy where resources are limited.

Regarding demographics, Talua lies clearly within the 'recent' model - the vast majority of students are under forty years of age, including married couples with children who attend the nearest school.

Hence, Talua combines both the 'historic' and 'recent' of Forman's taxonomy. Of the seven factors, one is 'historic' (economic), four are 'recent' (location, education, demographics and the shape of the teaching team) and two are both 'historic' and 'recent' (curriculum and study requirements). Hence Forman's bifurcated taxonomy fails to capture Talua's reality. It illuminates some challenges, including the value of remaining close to a culture, alongside the resultant pedagogical challenges, consistent with delivering theological education in what is still largely a subsistence economy. But ultimately, the taxonomy does not adequately represent the dynamics at play at Talua.

As well as considering Forman's taxonomy as applied to Talua, it is also worth considering it in relation to genesis and motivation. Fountain and Feener (2017) have noted the widespread use of taxonomies in mapping development, including in the religious domain. They argue that taxonomies are maps. Like all maps, they are not neutral, for they embody the values of the mapmaker. Forman's binary poles - of 'historic' and 'recent' - while illuminating the educative capability of theological education, contain an embedded set of value judgements. This is evident in Forman's claim that the recent pole offers theological education 'in the true sense' (Forman 1969, 156). Why is the 'recent' model more 'true' than the 'historic'? Forman writes as an expert on the South Pacific, yet his perspective is deeply shaped by his experience of living in the United States. During his thirty-four years teaching at Yale, he held roles as Chair of Theological Education Fund of the World Council of Churches and 
of the Commission on Ecumenical Mission and Relations of the Presbyterian Church. This may be why he asserts that the recent is 'true.' What he values in theological education involves quality improvements on a global scale in the mode of a modern American seminary, consistent with his role as Chair of an international body. The result is a map which carries implicit values, including a belief in the value of progress and that centralisation and standardisation benefit theological development. The results at Talua include students educated in ways that alienate them from local contexts and the danger of privileging the external at the expense of the local.

Given Forman's taxonomy has an embedded set of pedagogical values and is written from afar it raises the question of whether a Pacific theoretical frame might better guide an understanding of theological education in the Pacific. How might wayfaring interpret the interplay between external and local, which has emerged as a challenge for development and theological education?

WAYFARING: THEORISING THEOLOGICAL EDUCATION IN OCEANIA

'Oceania is vast, Oceania is expanding, Oceania is hospitable and generous ... Oceania is us'. (Hau'ofa 2008, 160)

We began this article with a story concerning the origins of theological education in Vanuatu and examined the ways that theological education in Vanuatu can be read as a retrieval account of local agency. We have also examined a binary taxonomy, of what Forman calls 'historic' and 'recent' models of theological education, but argued that such a frame is problematic in both application and motivation. This section offers a wayfaring narrative, through a focus on the ocean as a unitary and unifying body, to understand theological education as a contribution to development in the Pacific. In this reading, the dominant feature is not binary poles, but the ocean as a unifying body, a singular body of water that affords connections and weaves diversity into a shared adventure of knowledge exchange.

First, wayfaring is congruent with Pacific constructions of identity, which embody notions of wayfaring. For geographer Jerry Bentley (1999), ocean basins are important frames by which to understand cultural exchange. This is particularly important given that the Pacific Ocean accounts for thirty per cent of the earth's surface. For Epeli Hau'ofa (2008), the Pacific is a liquid continent, an interconnected whole. For centuries Pacific peoples have journeyed to exchange knowledge, culture, and goods, including obsidian, ochre, pottery, copra, tattoos, whale teeth, flax, and food. Sociologically, viewing the ocean as 
a vector for interaction and exchange has implications for development. Mar $(2016,66)$ has argued that any account of development in the Pacific needs to focus not on colonial arrivals, but rather on transnational lateral connections. Karin Amimoto Ingersoll $(2016,145)$ argues that for Pacific people, the ocean is an extension of 'self, avoiding the creation of a colonial ideology founded in binary oppositions'. This is consistent with Hau'ofa (2008), who sees oceanic wayfaring as an enlarging of worlds through the actions of voyaging.

A wayfaring narrative frame encourages a retrieval of local agency in theological education. It seeks ways to extend the self through knowledge exchange and trans-national connections, while challenging binaries of local and global as they apply to contextualisation and understandings of theological education in the Pacific. It is consistent with the hope of Talua: 'that Vanuatu, its church, its culture, its people, has a lot to offer to other people and countries' (Gillan $1988,323)$. It aligns with Mar's (2016, 224-5) argument that development in the Pacific is unique: an 'uncolonising' from inside out - a retrieval of identity, language, culture, and thought - through wayfaring. Hence the focus of theological education is an interconnected journey that weaves connections: neither dependent nor independent, but interdependent. Wayfaring encourages a knowledge exchange as part of an ancient flow, a way of enacting agency in ways unique yet interwoven.

Mar's work can be fruitfully located in relation to the work for epistemological decolonisation in other parts of the world. Mignolo notes the importance of asserting 'our modernity' as a first step in decolonisation (Mignolo 2011). Mignolo is drawing on the observation by Partha Chatterjee that the claim for a local (in Chatterjee's case Indian) perspective of 'our modernity' acts to locate the history of Britain as 'their modernity' - with different, albiet interwoven, trajectories. Applying this notion of 'our modernity', what Mar is doing in telling the unique story of decolonisation in the Pacific is offering an 'our' - that is, Oceanic - modernity. In the way Mar tells the story, she asserts Oceanic agency, ways of inter-connecting, and exchanging knowledge.

Further, Mar's 'our Oceanic' approach might then be of value to developments in epistemological decolonisation in other parts of the world. Specifically wayfaring, a uniquely Oceanic epistemology, might be a way to encounter the many 'our modernities' around the globe (Mignolo 2011, 35), not by relating back through Western universality, but in embarking on wayfaring voyages seeking a criss-cross of inter-connections and inter-change with any others who share an ocean shore. It then follows that Rakau is undertaking a similar task with regard to theological education. ${ }^{13}$ The story of two men swimming 
to a boat locates agency among the Ni-Vanuatu and narrates an 'our' - that is $\mathrm{Ni}$-Vanuatu - in relation to theological education. Colonial notions of centre and edge are displaced through the understanding of the ocean as a shared space for wayfaring adventure and interchange of knowledge.

Second, wayfaring is consistent with recent shifts in Christian missiology, away from the contextual and toward global theological flows. This is evident in the work of Catholic missiologist Robert Schreiter. In 1985, Schreiter wrote Constructing Local Theologies and argued for the value of the local and the essential role of context in theology. In 1999, he wrote The New Catholicity and examined the local not as a binary in contrast to the external. Rather Schreiter $(1999,16)$ called for a valuing of global theological flows, which he defined as 'circulating movements', a series of 'linked, mutually intelligible discourses that address the contradictions or failures of global systems. ${ }^{14}$ This approach is more consistent with a wayfaring focus, in which oceanic currents and global winds enable exchange. Using the wayfaring motif, Talua need not be located in just one of the sides of Forman's binary taxonomy. Rather it is one place in a circulating movement of discourses. This gives a theological institution like Talua value as an actor. It has agency, to enlarge self by swimming in Oceanic currents of contemporary knowledge.

Third, wayfaring would give voice to the brief descriptions of significant NiVanuatu leaders like Sethy Regenvanu or Fred Timakata. Gardner $(2013,126)$ noted a rise in political activism in Vanuatu as a result of regional engagement with the theological colleges of the Pacific. This activism can be understood within a wayfaring frame of understanding. An excellent example is that of $\mathrm{Ni}$-Vanuatu pastor and politician Sethy Regenvanu who, as a young man, completed an undergraduate theology degree at Pacific Theological College in Suva, Fiji in 1973. For his research thesis, Regenvanu analysed Paulo Freire's theories of adult education and argued for a reform in Christian education for the PCV. When Regenvanu returned to Vanuatu, he led changes in the way the Presbyterian church provided adult education and how theology was taught. His wayfaring enriched the local and helped develop education in Vanuatu. Another pastor who left Vanuatu to study later became the first Ni-Vanuatu clerk of the Presbyterian Assembly. Fred Timakata was exposed 'to a challenging Pacific-based theological training... urged to develop critical thinking and a high level of reflexivity on church and village, culture and the universal reception of the gospel' (Gardner 2013, 133-4). This trans-national flow enhanced Timakata's leadership in Vanuatu. These two brief descriptions illustrate the value of wayfaring as a way of understanding the interconnected patterns of theological education in the development of leadership in Vanuatu. In both 
cases, wayfaring allowed local Ni-Vanuatu leaders to be exposed to new approaches to pedagogy and critical thinking, which in turn they then applied back in Vanuatu, resulting in changes in education and in the church.

Our argument is that a wayfaring frame, which views theological education in the Pacific as the outcome of interconnected relationships, is useful in helping understand Talua. This has implications for past and future. In terms of the past, it provides a better frame than that posited by Forman, leaving Talua to be judged not as 'historic' or 'recent' but as originating in wayfaring. The binary divide between local and external, and the potential of those educated becoming 'alienated from their own people' (Rakau 1988, 12) is reframed by the wayfaring focus on the 'and' in the interplay between theological education and development. In terms of the future, it allows theological education to locate itself as neither exclusively historic and local nor global and centralised, but as part of a flow, a 'conceptualization of space that enables movement through imagination' (Ingersoll 2016, 139). Wayfaring today, including in theological education and development, can be enhanced by changes in technology. Ni-Vanuatu students no longer need to swim to knowledge in Samoa. Instead, they could 'dial up', downloading content which can be applied whether the context is the local village or the suburbs of Port Vila. In this wayfaring future, different islands in the Pacific would offer different expertise as part of the flow of theological currents across the Pacific. A full range of specialists and complete libraries (the teaching resources that enable educative 'capability') would not be needed in every physical location. Such an approach to theological education would retain the benefits of being local, including the attendant economic savings, while offering an education that exposes students to the catholicity inherent in higher education. Theological education as wayfaring could be animated by contemporary technologies in ways that would nurture an 'interconnected' way of being in Oceanic theological education while subverting the privileging of centralising models. Wayfaring provides a way to enhance theological education, offering a way to appreciate local and external as trans-nationally connected.

Having explained and applied a wayfaring narrative, arguing for its contextual, decolonising and missiological relevance, we do need to remind ourselves that a wayfaring frame of analysis is not without potential weaknesses. While water might be a playful companion, it can equally be a bringer of hurricane and tidal wave. Oceanic metaphors might make less sense to those communities that live in the mountains of Vanuatu. Wayfaring runs the risk of romanticisation, a theological 'Moana', a Hollywood gloss on a rich and complicated history (Taylor 2017). Despite these reservations, the fact that it emerges from a 
Ni-Vanuatu story, of two men swimming toward a voyage and is grounded in Pacific history, culture and epistemology, ensures both general (Pacific) and particular (Ni-Vanuatu) frames of reference.

\section{A NEW SIGN OF A WAYFARING FUTURE}

The argument that education is essential to development has been tested through an empirical study of a particular theological college. Using a frame of educative capability challenges a secularising approach to development, which neutralises or even scorns the role of Christianity, and by extension theological education. In Vanuatu, at Talua and its antecedents, theological education has been a development actor: encouraging local agency, resourcing literacy, respecting equality among diverse ethnicities, affirming cultural diversity while playing a role in forming national identity, and providing leaders for an independent nation. These are significant dimensions in expanding the richness of human life in Vanuatu.

Our analysis of Talua has also resulted in a critique of a historic and influential taxonomy used to describe theological education in the Pacific. Forman's taxonomy is helpful in illuminating development in relation to educative 'capability', allowing theological education to be analysed with regard to economic sustainability, pedagogy, and contextuality. However, Forman's frame does not adequately capture the reality of Talua. Rather, his implicit narrative of progress and affirmation of centralising approaches to education has been critiqued, as supporting ways of thinking that create binaries between local and external.

Our analysis has also established mutual concerns shared by both development and theological education. Both wrestle with the interplay between local and external: whether in seeking to affirm local agency in 1849 or ensuring that financial gifts from external donors in 1980 do not result in abandoned concrete buildings. This makes the wayfaring narrative significant. It provides a focus not on context as either local or external. Rather it brings into focus the 'and' in which a singular Oceanic body of water encourages connections and weaves diversity into a shared adventure of knowledge exchange. Wayfaring respects and connects multiple contexts, whether local or external, whether village or Port Vila. It offers a way for Talua in particular, and theological education and development in general, to understand their past and consider their future, as part of an Oceanic (and thus global) theological flow, always local, forever valuing knowledge exchange, not as foreign, but as Oceanic. It is a movement of decoloniality (Mignolo 2011, 23-24), an Oceanic 'our modernity' that might 
be of value to developments in epistemological decolonisation in other parts of the world.

We introduced theological education in Vanuatu with a story from the past. We end with a story from today. In 2017, one of the authors was part of an experiment in wayfaring, a Faculty exchange between the theological colleges of the Presbyterian Churches of Vanuatu and New Zealand. While visiting Talua, the College unveiled their new signs, including one depicting a person in a canoe travelling toward a 'passion for mission'. The sign had three colours - black, yellow and green. Any journey has movement and in the sign, a cross, a symbol of Christian faith, was tilted in ways that suggested a movement toward a yellow sun. This is a reflection on gospel and culture, of moving toward a new dawn and a bright future (Pastor Selerik, pers. com., 2017). It was certainly consistent with the speech made by the Governor of Espiritu Santo at the unveiling, affirming the role and importance of Talua as a theological college in the development, social and economic, of Vanuatu.

The boat, the cross holder and the cross were coloured green, suggesting a shared affinity, as people transformed by Christian faith. This transformation provides agency, for people are becoming wayfarers. The presence of Talua as a college of theological education means that $\mathrm{Ni}$-Vanuatu are now no longer waiting on a passing ship. Nor need they accept foreign exchange in order to build concrete buildings. Instead, some 170 years after the two men swam, they can now be wayfarers for themselves. They can draw on bush materials rather than expensive imported concrete, to set up temporary shops, as needed. Mission and formal education are no longer 'over there', in a distant place. They are part of the Ni-Vanuatu experience, in ways that invite local agency, as people take responsibility for their own future. The invitation of this passion for mission being offered by Talua as a local actor is for the people of Vanuatu to set sail, taking Vanuatu, its church, its culture, its people to other people and places (Gillan 1988, 323). They are primary development actors, seeking ocean currents, powered by an experience of theological education that gives them courage as wayfarers.

\section{ACKNOWLEDGEMENTS}

We are grateful to the Harrison Bequest, which paid for one of the authors to travel to Talua for a ten-day immersion experience in 2017. 
NOTES

1 Steve Taylor is Principal, Knox Centre for Ministry and Leadership and Senior Lecturer, Flinders University, Australia. Born in Papua New Guinea, he has published academically in missiology and popular culture.

Email: principal@knoxcentre.ac.nz

2 Phil King is an ordained Presbyterian minister and is currently the Global Mission Co-ordinator, Presbyterian Church of Aotearoa New Zealand (PCANZ). The PCANZ's deepest level of overseas partnership is with the Presbyterian Church of Vanuatu. This paper emerges from the wayfaring that in times past has marked their partnership.

Email: phil@presbyterian.org.nz

3 Presbyterian missionary John Haysey is quoted as noting that, on the day Vanuatu became independent, 'someone said to me "There is too much religion in this". I replied "You have to understand these people of these islands and depth of their spiritual values as well as their Melanesian values"' (Gillan 1988).

4 For an account see Molisa and colleagues (1982).

5 Thanks to the staff at the Archives Research Centre of the Presbyterian Church of Aotearoa New Zealand and the Hocken Collections, University of Otago, Dunedin for their tending of taonga.

6 This included a 2017 faculty exchange between the theological colleges of the Presbyterian churches of Vanuatu and New Zealand.

7 In Vanuatu, looking for a boat to travel between islands is described as looking for a road (Brocket 1973, 69).

8 In this section we have drawn extensively on history as told by Fiama Rakau (1988). His focus is on the motives and purpose of theological education. Motive does not always translate easily into reality (Bray 1991). Despite this caution, the records show a retrieval, valuing local empowerment and expressing a commitment to development.

9 Rakau (1988, 6), citing Tangoa Training Institution.

10 'Our primary object was to teach them to read, that they might be able to read the Bible and learn the will of God ... for themselves' (Rakau 1988, 3). 
11 In particular, pastor, theological educator, and finally politician, Sethy Regenvanu.

12 In a report, a three-person team reviewing Theological Education in the South Pacific, concluded that Vanuatu was 'the poorest in standard of training' (Rakau $1988,16)$.

13 In making this suggestion, We are aware that Mignolo is not convinced that Christianity can move 'beyond Zero-point epistemology', defined by Mignolo $(2011,40)$ as 'the historical fusion between Christian theology and sixteenthcentury Western cartography'. Hence Mignolo might be uneasy about theological education being described as an agent in decolonisation. Our response is to locate our task as narrating a Ni-Vanuatu account of theological education in conversation with Oceanic understandings of decolonisation and in light of the interwoven history that is Christianity and the Pacific.

14 Schreiter acknowledges he is borrowing from Peter Beyer's (1994, 96-110) concept of antisystemic global flows in Religion and Globalization.

\section{REFERENCES}

Bentley, Jerry. 1999. 'Ocean Basins as Frameworks of Historical Analysis'. Geographical Review 89 (2):215-224.

Bray, Melissa S. 1991. 'The planting of an indigenous church: moves towards the inauguration of the Presbyterian Church in the New Hebrides in 1948'. BA (Hons) thesis. Dunedin: University of Otago.

Brocket, Duncan. 1973. Workparty to the New Hebrides. Held at Hewitson Library, Presbyterian Church of Aotearoa New Zealand, Dunedin

Brooks, James, Christopher R. DeCorse, and John Walton. 20o8. Small Worlds: Method, Meaning, and Narrative in Microhistory. Santa Fe, NM: School for Advanced Research Press.

Edmond, Rod. 2013. Migrations: Journeys in Time and Place. Wellington: Bridget Williams Books.

Forman, Charles. 1969. 'Theological Education in the South Pacific Islands: A Quiet Revolution'. Journal de la Societe des Oceanistes 25 (25):151-167. 
- 1994. 'The Study of Pacific Island Christianity: Achievements, Resources, Needs'. International Bulletin of Missionary Research 18 (3):103-112.

_. 1994. 'Our Own Voice: The Reinterpreting of Christianity by Oceanian

Theologians'. International Bulletin of Missionary Research 18 (3):115-122.

1982. The Island Churches of the South Pacific. Maryknoll: Orbis.

Fountain, Philip, and R. Michael Feener. 2017. 'Navigating a World of Religious NGOs: Ethnography, Abstraction, and the Views of the Horizon'. Geography Compass 11 (10):1-11.

Gardner, Helen. 2013. 'Praying for Independence: The Presbyterian Church in the Decolonisation of Vanuatu'. The Journal of Pacific History 48 (2):122-143.

Gillan, Helen Rose. 1988. Vanuatu Victory: Four Generations of Sharing Christian Faith in the Pacific. Spectrum: Victoria, Australia.

Ginzburg, Carlo. 2012. Threads and Traces: True, False, Fictive. Trans. by Anne C Tedeschi and John Tedeschi. Berkeley: University of California Press.

Gorringe, Timothy. 2004. Furthering Humanity: A Theology of Culture. Aldershot: Ashgate.

Hau'ofa, Epeli. 2008. 'Our Sea of Islands'. In We are the Oceans: Selected Works, 27-41. Honolulu: University of Hawaii Press.

HDro Outreach. 2018. 'What is Human Development?' Accessed 8 March 2018 from http://hdr.undp.org/en/content/what-human-development

Ingersoll, Karin Amimoto. 2016. Waves of Knowing: A Seascape Epistemology. Durham: Duke University Press.

Lockwood, Victoria. 2004. 'The Global Imperative and Pacific Island Societies'. In Globalization and Culture Change in the Pacific Islands, edited by Victoria Lockwood, 1-39. Upper Saddle River, NJ: Pearson Prentice Hall.

Magnusson, Sigurdur Gylfi. 'History News Network | What Is Microhistory?' Accessed 2 August 2016 from http://historynewsnetwork.org/article/23720 
McDougall, Debra. 2016. Engaging with Strangers: Love and Violence in the Rural Solomon Islands. New York: Berghahn Books.

McFarlane, Robert. 2012. The Old Ways: A Journey on Foot. London: Hamish Hamilton.

Makikon, Reuben. 1988. Speech Opening Talua Ministry Training Centre on the 24th August - 1988. Held at Archives Research Centre, Presbyterian Church of Aotearoa New Zealand, Dunedin, '97, 94/62. Comec, J. Sec (Al). Sbjct Vanuatu. 1985-1989.

Mar, Tracey Banivanua. 2016. Decolonisation and the Pacific: Indigenous Globalisation and the Ends of Empire. Cambridge: Cambridge University Press.

Mitchell, Jean. 2004. "Killing Time” in a Postcolonial Town: Young People and Settlement in Port Vila, Vanuatu'. In Globalization and Culture Change in the Pacific Islands, edited by Victoria Lockwood, 358-376. Upper Saddle River, NJ: Pearson Prentice Hall.

Mignolo, Walter. 2011. 'Decolonizing Western Epistemology/Building Decolonial Epistemologies'. In Decolonizing Epistemologies: Latina/o Theology and Philosophy, edited by Ada Maria Isasi-Diaz and Eduardo Mendieta, 19-45. New York: Fordham University Press.

Molisa, Grace, Nikenike Vurobaravu, and Howard Van Trease. 1982. 'Vanuatu: Overcoming Pandemonium'. In Politics in Melanesia vol 1, edited by Ahmed Ali and Ron G. Crocombe, 82-115. Fiji: Institute of Pacific Studies of the University of the South Pacific.

Pacific Vanuatu Talua Ministry Training Centre, XG-8, 6. Held at Archives Research Centre, Presbyterian Church of Aotearoa New Zealand, Dunedin, '97, 94/62. Comec, J. Sec (Al). Sbjct Vanuatu. 1985-1989'.

Presbyterian Church of Vanuatu 1989. Newsletter No. 21, March 1989. Held at Archives Research Centre, Presbyterian Church of Aotearoa New Zealand, Dunedin, '97, 94/62. Comec, J. Sec (Al). Sbjct Vanuatu. 1985-1989'.

Rakau, Fiama, 1988. From Aname to Talua. A Brief Survey of Theological Education in Vanuatu, July 1988. Held at Archives Research Centre, Presbyterian Church of Aotearoa New Zealand, Dunedin, '97, 94/62. Comec, J. Sec (Al). Sbjct Vanuatu. 1985-1989'. 
Schreiter, Robert J. 1999. The New Catholicity: Theology between the Global and the Local. Maryknoll: Orbis.

-1985. Constructing Local Theologies. Maryknoll: Orbis.

Sen, Amartya. 1985. Commodities and Capabilities. Amsterdam: North-Holland.

Talua Committee Report to the 4oth PCV General Assembly, Vanuatu PCV General Assembly Reports, 1988, 28. Held at Archives Research Centre, Presbyterian Church of Aotearoa New Zealand, Dunedin, '97, 94/62. Comec, J. Sec (Al). Sbjct Vanuatu. 1985-1989'.

Taylor, Steve. 2017. 'Moana'. Touchstone February: 14.

Te Paa-Daniel, Jenny. 2018. 'Our Church Leaders Need to See Jesus as a Radical Activist.' 4 March 2018. Accessed 8 March 2018 from https://e-tangata.co.nz/ news/our-church-leaders-need-to-see-jesus-as-a-radical-activist

Vanuatu Talua Project, Talua Ministry Training Centre, Staff and Curriculum Committee - Report No. 2, 15-16 July, 1985, 2.41. Held at Archives Research Centre, Presbyterian Church of Aotearoa New Zealand, Dunedin, '97, 94/62. Comec, J. Sec (Al). Sbjct Vanuatu. 1985-1989'.

Whimp, Neal, The Church in Vanuatu since 1945 with Special Reference to its Role in the Move to Independence, 1980. Annual lecture, Christchurch, 1981. Held at Hocken Collections, University of Otago, Dunedin.

Young, Michael. 2004. Malinowski: Odyssey of an Anthropologist 1884-1920. New Haven and London: Yale University Press. 